\title{
Effect of immunosuppression on the human mesangial cell cycle
}

\author{
XIAOSHUANG ZHOU ${ }^{1}$, BIRUH WORKENEH ${ }^{2}$, ZHAOYONG HU ${ }^{2}$ and RONGSHAN LI ${ }^{1,3}$ \\ ${ }^{1}$ Department of Nephrology, Provincial People's Hospital of Shanxi Medical University, Taiyuan, \\ Shanxi 030001, P.R. China; ${ }^{2}$ Department of Nephrology, Baylor College of Medicine, \\ Houston, TX 77030, USA; ${ }^{3}$ Department of Nephrology, Shanxi Provincial People's Hospital, \\ Taiyuan, Shanxi 030001, P.R. China
}

Received April 10, 2014; Accepted July 22, 2014

DOI: $10.3892 / \mathrm{mmr} .2014 .2861$

\begin{abstract}
The present study investigated the effects of immunosuppressive agents [tacrolimus (Tac), cyclosporine A (CsA), mycophenolic acid (MMF) and methylprednisone (MP)] on the proliferation, cell cycle progression and apoptotic rate of human mesangial cells. Cultured human mesangial cells were treated with several concentrations of the immunosuppressive agents for 24,48 or $72 \mathrm{~h}$. Cell cycle progression, proliferation and apoptosis were analyzed using an MTT assay and flow cytometry. Tac and CsA significantly inhibited the proliferation of human mesangial cells in a dose- and time-dependent manner. Cell cycle analysis revealed that Tac and CsA arrested mesangial cells in the $G_{0} / G_{1}$ phase, preventing them from entering $S$ phase. Similarly, MP inhibited human mesangial cell growth by causing cell cycle arrest in $\mathrm{G}_{0} / \mathrm{G}_{1}$ phase. $\mathrm{MMF}$ also inhibited mesangial cell proliferation, but accomplished this by preventing progression from $S$ phase to the $G_{2} / M$ phase. The combination of MP and MMF synergistically inhibited mesangial cell proliferation. Tac, CsA, MP and MMF inhibited proliferation of human mesangial cells by blocking progression of the cell cycle. In conclusion, these agents, sequentially or in combination, may be used to effectively treat mesangial proliferative glomerular disease.
\end{abstract}

\section{Introduction}

Several glomerular diseases, including focal segmental glomerulosclerosis (FSGS) variants, immunoglobulin A (IgA)nephropathy and lupus nephritis are associated with mesangial cell proliferation and expansion (1). Thus, immunosuppressive agents that have an inhibitory effect on mesangial cell expansion and proliferation are of considerable interest. Patients with glomerulonephritis involving mesangial

Correspondence to: Dr Rongshan Li, Department of Nephrology, Provincial People's Hospital of Shanxi Medical University, 29 Shuang Ta East Street, Taiyuan, Shanxi 030001, P.R. China E-mail: rongshanli13@163.com

Key words: cell cycle, mesangial cell, calcineurin-inhibitors, methylprednisolone, mycophenolic acid proliferation are often treated with agents including corticosteroids, calcineurin-inhibitors, cyclophosphamide (CyA) and anti-metabolites such as mycophenolic acid (MMF). These agents have narrow therapeutic windows and serious side-effects $(2,3)$. Combination and sequential therapy using various immunosuppressive agents have been used to successfully treat kidney transplant recipients and myelogenous leukemia patients (4-6). Therefore, it was hypothesized that a complementary or sequential immunosuppressant treatment strategy may be capable of effectively suppressing human mesangial cell proliferation. The aim of the present study was to acquire more information regarding the effects of these immunosuppressive agents on the cell cycle progression of human mesangial cells and to investigate whether a combination of these agents may result in a more effective suppression of mesangial cell proliferation.

Inflammation or cell injury triggers mesangial cell proliferation, which causes activation and progression of the cell cycle. Interfering with processes at any stage of the cell cycle can arrest proliferation or promote apoptosis (7). Drugs commonly used to treat glomerulonephritis include tacrolimus (Tac), cyclosporine A (CsA), methylprednisone (MP) and MMF. Several studies have demonstrated that these agents can inhibit the proliferation of mesangial cells and may therefore be effectively used to treat glomerular disease (1,8-11). However, a detailed explanation regarding the effect that these drugs exert on the human mesangial cell cycle is lacking. Knowledge of the mechanism of the effects of these drugs on the cell cycle is of potential use in disease monitoring and treatment of glomerular disorders. The present study investigated how each of these agents influenced the proliferation, apoptosis and cell cycle progression of human mesangial cells using a dose-escalation and sequential approach.

\section{Materials and methods}

Cell cultures. A human mesangial cell line T-SV40, provided by Dr Li Xuewang at Peking Union Medical College Hospital (Beijing, China) $(12,13)$, was cultured at $37^{\circ} \mathrm{C}$ in a humidified 5\% $\mathrm{CO}_{2}$ atmosphere with RPMI-1640 medium (Sigma, St. Louis, MO, USA) containing $10 \%$ fetal calf serum (FCS; Sijiqing Biological Engineering Materials Co., Ltd., Hangzhou, China). Prior to stimulating proliferation, 60\%-confluent 

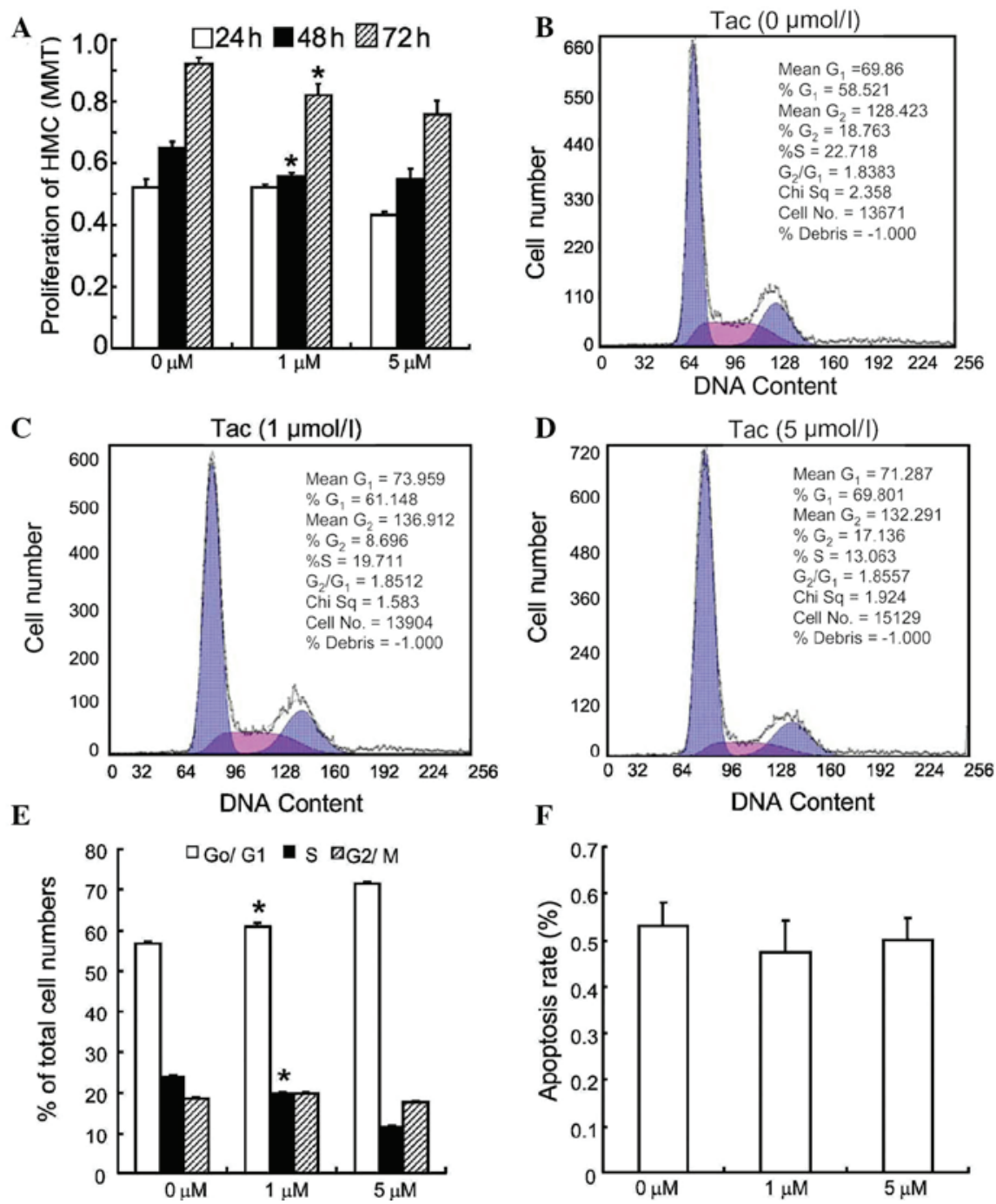

Figure 1. Tac prevents progression of the cell cycle of $H M C s$ from $\mathrm{G}_{0} / \mathrm{G}_{1}$ to $\mathrm{S}$ phase. (A) Quiescent HMCs were treated with $10 \%$ fetal calf serum in the absence or presence of Tac ( 1 and $5 \mu \mathrm{mol} / \mathrm{l})$ and their proliferation was assessed via MTT assay at 24,48 and $72 \mathrm{~h}\left({ }^{*} \mathrm{P}<0.05 \mathrm{vs} .0 \mu \mathrm{mol} / \mathrm{l}\right)$. (B-D) Cell cycle progression of HMCs in response to various concentrations of Tac was analyzed by flow cytometry $48 \mathrm{~h}$ following treatment. (E) Statistical analysis indicated that upon exposure to 1 and $5 \mu \mathrm{mol} / 1 \mathrm{Tac}$ for $48 \mathrm{~h}$, the percentage of $\mathrm{HMCs}$ in the $\mathrm{S}$ phase and $\mathrm{G}_{0} / \mathrm{G}_{1}$ phase was significantly altered ("P $\left.<0.01 \mathrm{vs} .0 \mu \mathrm{mol} / \mathrm{l}\right)$. (F) HMCs were treated with Tac $(1$ and $5 \mu \mathrm{mol} / \mathrm{l})$ for $48 \mathrm{~h}$ and the apoptotic rate was assessed by flow cytometry. All values are presented as the mean \pm standard deviation values of three independent experiments. Tac, tacrolimus; HMC, human mesangial cell.

cells were starved in serum-free medium for $24 \mathrm{~h}$ and then treated with medium containing $10 \%$ FCS and various immunosuppressive agents. Cells were used at passage 17 and no mycoplasmic infection was detected.

MTT assay. Human mesangial cells were seeded at a density of $1 \times 10^{5} / \mathrm{ml}$ into 96 -well plates for $24 \mathrm{~h}$. Each plate contained three wells of each experimental condition and three control wells. Following treatment with various immunosuppressive agents for 24,48 or $72 \mathrm{~h}$, cells were incubated with MTT $(0.5 \%$, Sigma $)$ for $4 \mathrm{~h}$ at $37^{\circ} \mathrm{C}$. The medium was subsequently removed and $150 \mu \mathrm{l}$ dimethyl sulfoxide (Sigma-Aldrich, Beijing, China) was added to each well prior to measuring the absorbance $(490 \mathrm{~nm}$, model 550, Bio-Rad, Hercules, CA, USA).

Cell cycle analysis. Cell cycle progression was assessed by flow cytometry (FCM). Human mesangial cells were seeded at a density of $\sim 1 \times 10^{5} / \mathrm{ml}$ in six-well plates for $24 \mathrm{~h}$ prior to the addition of various immunosuppressive agents, including TAC,
CsA, MP and MMF (all Sigma-Aldrich) for 24, 48 or $72 \mathrm{~h}$. Cells were collected, fixed in $1 \%$ methanol-free formaldehyde (Sigma-Aldrich) for $20 \mathrm{~min}$ and suspended in $70 \%$ ethanol solution to dehydrate for $24 \mathrm{~h}$ at $-20^{\circ} \mathrm{C}$. Cells were washed with phosphate-buffered saline (PBS; Sigma-Aldrich) and incubated in PBS containing RNAse for $10 \mathrm{~min}$ at room temperature. Finally, $200 \mu \mathrm{l}$ propidium iodide solution was added to each well for $10 \mathrm{~min}$ on ice to stain the nuclei. Samples were immediately examined by FCM using a FACstar Plus cytometer (BectonDickinson, Mountain View, CA, USA) and the results analyzed by Cell Quest software (Becton-Dickinson). Each experiment was performed three times, and the ratio of cells in the $G_{0} / G_{1}, S$ and $\mathrm{G}_{2} / \mathrm{M}$ phases was determined and expressed as the mean \pm standard deviation (SD).

Cell apoptosis analysis. Apoptotic cells were detected by FCM. Human mesangial cells were seeded at a density of $\sim 1 \times 10^{5} / \mathrm{ml}$ in six-well plates for $24 \mathrm{~h}$. Following administration of various immunosuppressive agents for 24,48 or $72 \mathrm{~h}$, cells 
A

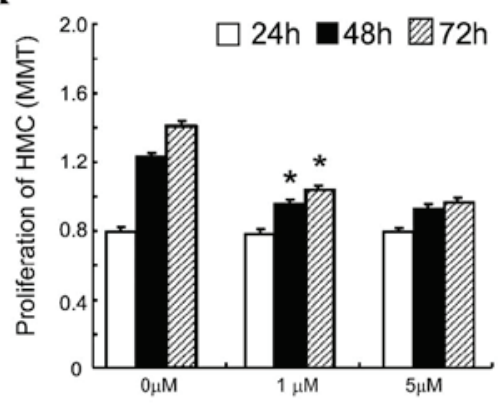

C

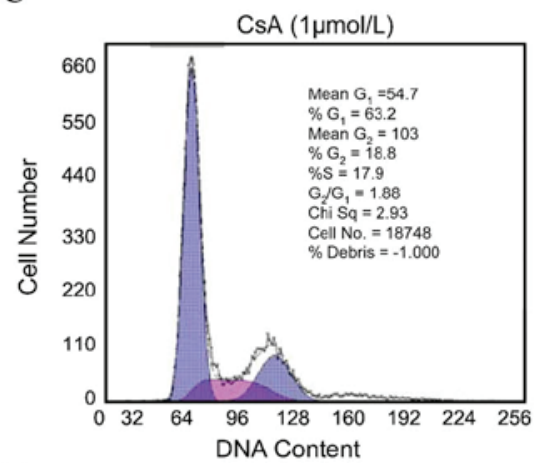

$\mathbf{E}$

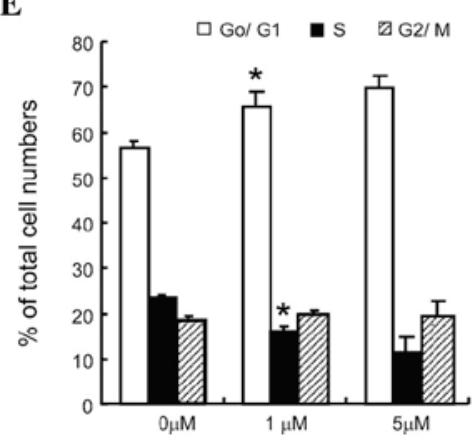

B

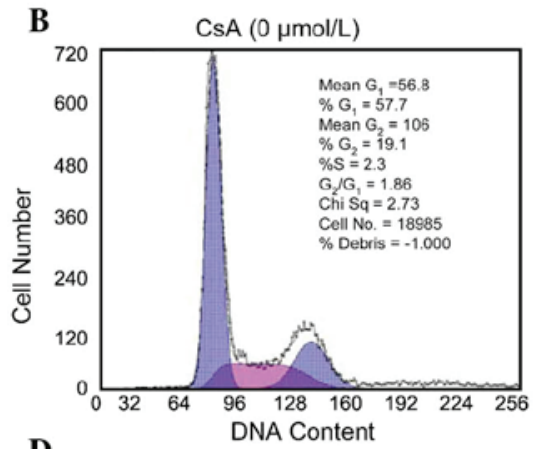

D

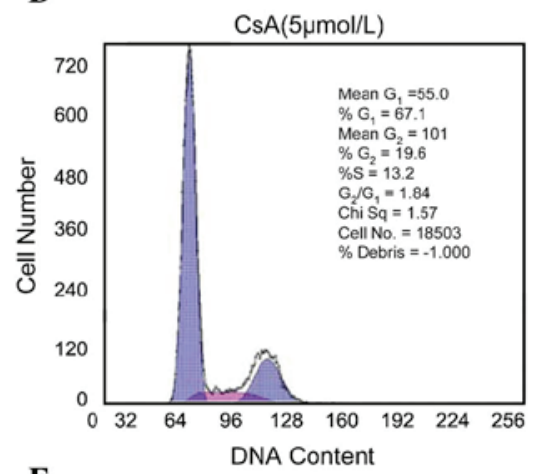

$\mathbf{F}$

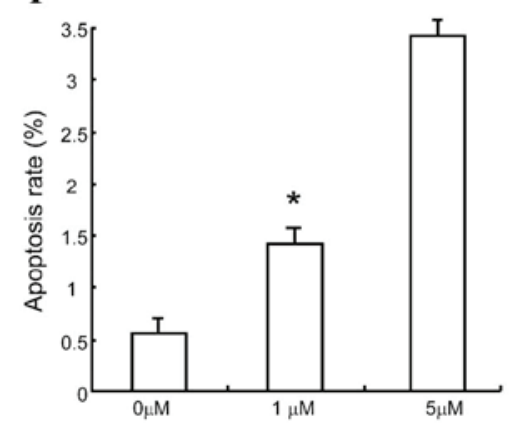

Figure 2. CsA causes HMC growth arrest at the $\mathrm{G}_{0} / \mathrm{G}_{1}$ phase. (A) Quiescent HMCs were stimulated by $10 \%$ fetal calf serum with or without CsA (1 and $5 \mu$ mol/l) for 24, 48 and $72 \mathrm{~h}$, and proliferation was examined by an MTT assay ("P<0.001 vs. $0 \mu \mathrm{mol} / 1$ ). (B-D) Representative flow cytometry results of HMC cycle analysis (control and CsA at 1 and $5 \mu \mathrm{mol} / 1$ for $48 \mathrm{~h}$ ). (E) Statistical analysis results of B-D ("P<0.01 vs. $0 \mu \mathrm{mol} / 1)$. (F) HMCs were treated with CsA ( 1 and $5 \mu \mathrm{mol} / 1$ ) for $48 \mathrm{~h}$ and apoptotic rates were measured by flow cytometry ("P $<0.01 \mathrm{vs} .0 \mu \mathrm{mol} / \mathrm{l}$ ). All values are presented as the mean \pm standard deviation of three independent experiments. CsA, cyclosporine A; HMC, human mesangial cell.

were collected, washed with PBS and adjusted to a density of $\sim 1 \times 10^{6} / \mathrm{ml}$ with PBS. $100 \mu 1$ cell suspension was transferred into tubes containing $5 \mu \mathrm{l}$ Annexin V/fluorescein isothiocyanate (Life Technologies, Grand Island, NY, USA) and $10 \mu 1$ propidium iodide solution. The cells were fixed for $15 \mathrm{~min}$ in the dark. Finally, $400 \mu$ l PBS was added to each tube and the contents immediately analyzed with the flow cytometer (Becton-Dickinson) to detect apoptosis.

Statistical analysis. All experiments were repeated three times and results were presented as the mean \pm SD. The treatment effects were analyzed by one-way analysis of variance using Sigma stat 3.5 (Systat Software, San Jose, CA, USA) to test differences amongst the groups. $\mathrm{P}<0.05$ was considered to indicate a statistically significant difference between values.

\section{Results}

Tacrolimus. The effects of Tac on the cell cycle of human mesangial cells were examined, firstly by treating human mesangial cells with Tac (1-5 $\mu \mathrm{mol} / \mathrm{l})$ and assessing their proliferation by an MTT assay. Cellular proliferation was significantly decreased following Tac treatment. This inhibitory effect occurred in a dose- and time-dependent manner (Fig. 1A). The effects of Tac on cell cycle progression were then examined (Fig. 1B-D). Upon exposure to $5 \mu \mathrm{mol} / 1$ Tac for $48 \mathrm{~h}$, the percentage of cells in the $\mathrm{S}$ phase decreased by $41 \%$, while the percentage of cells in $\mathrm{G}_{0} / \mathrm{G}_{1}$ phase increased by $30 \%$. These results indicated that Tac prevented the progression of human mesangial cells into $S$ phase (Fig. 1E). The effects of Tac on apoptosis of human mesangial cells were also examined. Tac (at 1 and $5 \mu \mathrm{mol} / \mathrm{l}$ ) did not significantly alter the apoptotic rate of human mesangial cells following $48 \mathrm{~h}$ of treatment (Fig. 1F).

Cyclosporine A. As in the case of Tac, when human mesangial cells were exposed to CsA ( 1 and $5 \mu \mathrm{mol} / \mathrm{l})$ in a dose- and time-dependent manner, cellular proliferation was inhibited (Fig. 2A). Following $48 \mathrm{~h}$ of exposure to CsA (1 and $5 \mu \mathrm{mol} / \mathrm{l}$ ), the percentage of cells in $\mathrm{S}$ phase was 
A
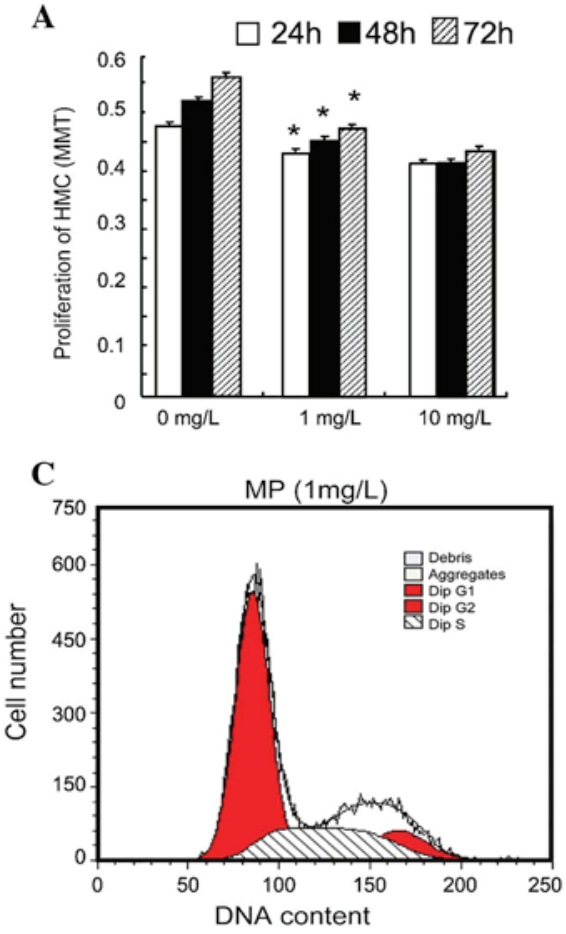

E

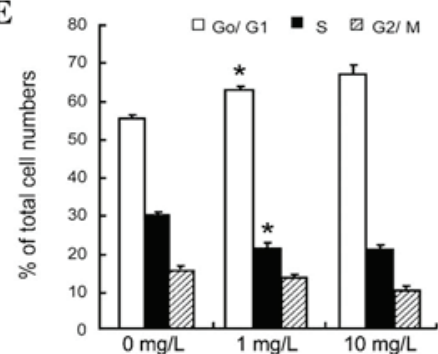

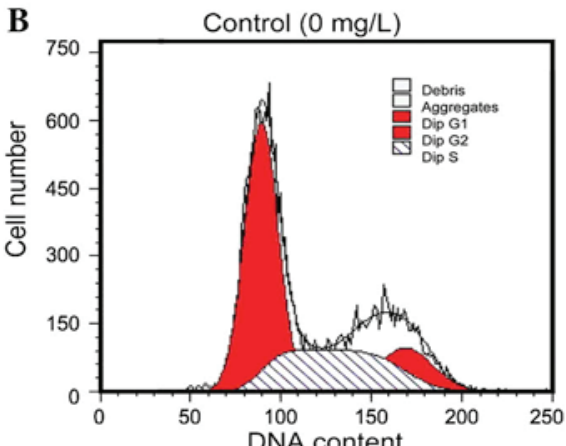

D

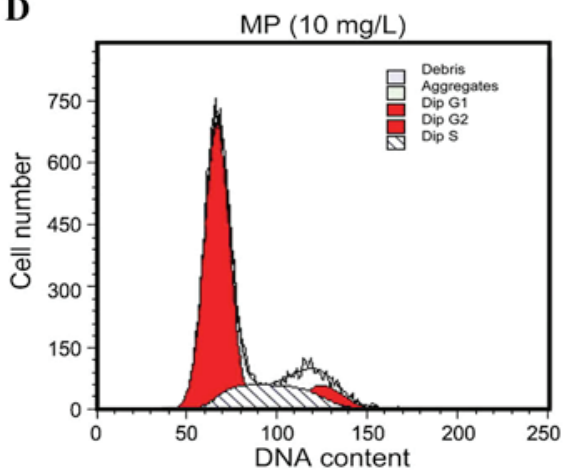

$\mathbf{F}$

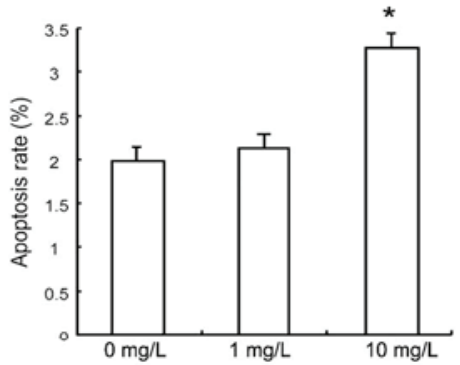

Figure 3. MP prevents HMCs from entering S phase. (A) Quiescent HMCs were treated with $10 \%$ fetal calf serum in the absence and presence of MP ( 1 and $10 \mathrm{mg} / \mathrm{l}$ ) and subjected to an MTT assay ("P<0.05 vs. $0 \mathrm{mg} / \mathrm{l}$ ). (B-D) At $48 \mathrm{~h}$, the cell cycle progression was assessed by flow cytometry. (E) Statistical analysis of B-D ("P<0.05 vs. $0 \mu \mathrm{mol} / \mathrm{l}$ ). (F) Statistical analysis of the apoptotic rate assessed by flow cytometry. At $10 \mathrm{mg} / \mathrm{l}$ for $48 \mathrm{~h}$, MP significantly increased apoptosis in HMCs ("P<0.01 vs. $0 \mu \mathrm{mol} / \mathrm{l})$. Values are expressed as the mean \pm standard deviation of six independent experiments. MP, methylprednisolone; HMC, human mesangial cell.

significantly decreased and there was a significant increase in the percentage of cells in the $\mathrm{G}_{0} / \mathrm{G}_{1}$ phase (Fig. 2B-D). This indicated that CsA arrested human mesangial cells prior to their entry into $S$ phase (Fig. 2E). Finally, the effects of CsA on apoptosis of human mesangial cells were assessed. When cells were exposed to CsA ( 1 and $5 \mu \mathrm{mol} / \mathrm{l})$ for $48 \mathrm{~h}$, the percentage of apoptotic cells significantly increased in a dose-dependent manner (Fig. 2F).

Methylprednisolone. The influence of MP on human mesangial cell growth has not previously been studied, to the best of our knowledge. At concentrations of 1 and $10 \mathrm{mg} / \mathrm{l}, \mathrm{MP}$ inhibited the proliferation of human mesangial cells in a doseand time-dependent manner (Fig. 3A). It was also determined that at concentrations of 1 and $10 \mathrm{mg} / \mathrm{l}$, MP significantly decreased the percentage of cells in $\mathrm{S}$ phase, while increasing the percentage of cells in $G_{0} / G_{1}$ phase (Fig. 3B-E). Similarly to CsA, MP (1-10 mg/l) significantly increased the apoptotic rate in human mesangial cells following $48 \mathrm{~h}$ of treatment (Fig. 3F).
Mycophenolic acid. The present study investigated how MMF influenced the proliferation of human mesangial cells and found that $0.25-10 \mu \mathrm{mol} / 1 \mathrm{MMF}$ significantly inhibited the proliferation of human mesangial cells following 24,48 or $72 \mathrm{~h}$ of treatment (Fig. 4A). MMF also significantly suppressed the entry of cells into $G_{2} / M$ phase, causing cell cycle arrest in the $S$ phase (Fig. 4B-E). As shown in Fig. 4F, there was a significant increase in the early apoptotic rate of human mesangial cells that were treated for $48 \mathrm{~h}$ with MMF.

Immunosuppressants inhibit proliferation and cell cycle progression of human mesangial cells. The effects of Tac, CsA, MP and MMF on human mesangial cell cycle progression are summarized in Fig. 5A. Since MMF is often used with adjunctive immunosuppressants, human mesangial cells were treated with $2.5 \mathrm{mmol} / \mathrm{l} \mathrm{MMF}$ in order to block cells in the $S$ phase from entering into $\mathrm{G}_{2} / \mathrm{M}$ phase and $1 \mathrm{mg} / \mathrm{l} \mathrm{MP}$ to block cells progressing from $\mathrm{G}_{0}$ phase to $S$ phase. This combination of drugs inhibited the proliferation of mesangial cells more efficiently than each drug separately (Fig. 5B). This 
A

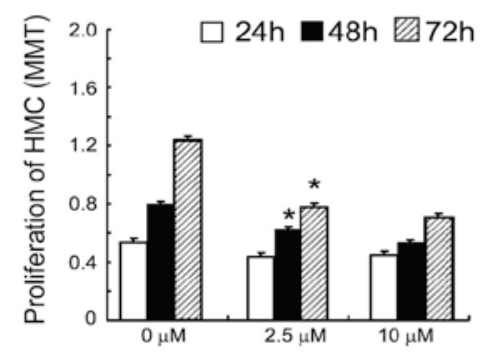

C

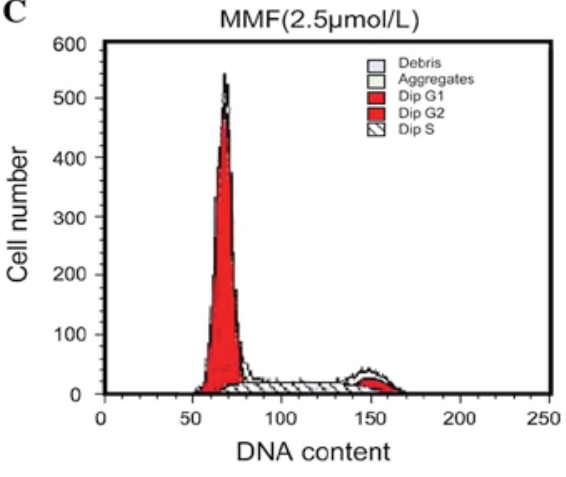

E

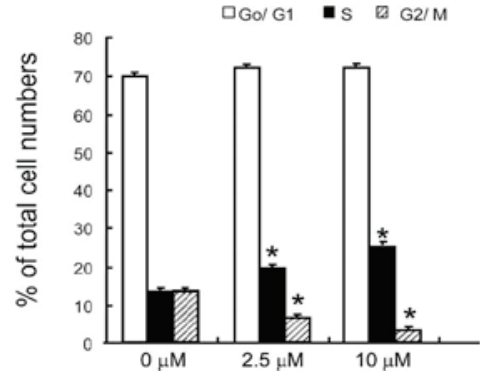

B

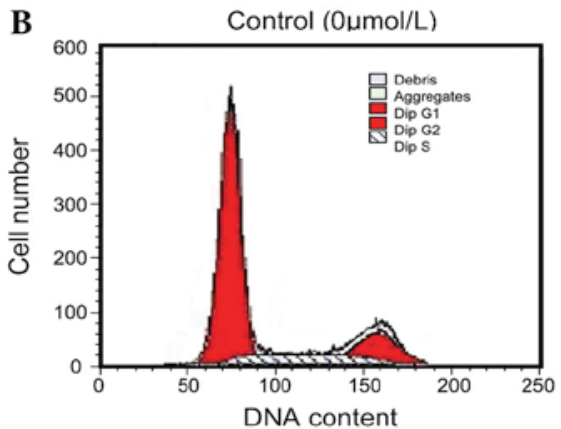

D

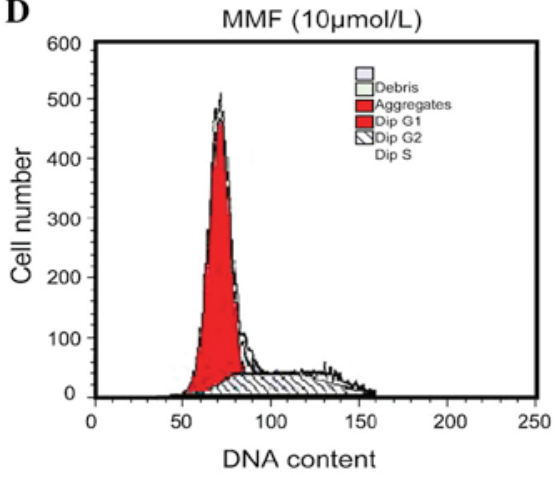

F

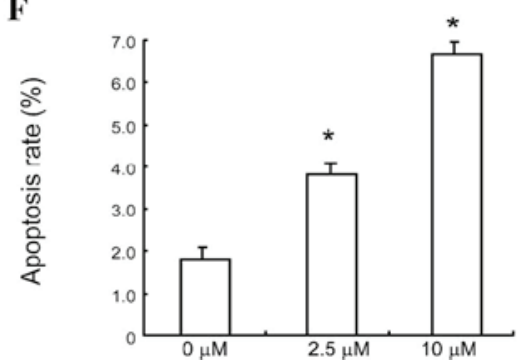

Figure 4. MMF blocks entry of HMCs into $\mathrm{G}_{2} / \mathrm{M}$ phase. (A) Quiescent HMCs were treated with MMF for 24, 48 or $72 \mathrm{~h}$. The proliferative rate was assessed using an MTT assay ( $\mathrm{P}<0.01 \mathrm{vs} .0 \mu \mathrm{mol} / \mathrm{l})$. (B-D) The cell cycle of HMCs was analyzed by flow cytometry following $48 \mathrm{~h}$ of treatment. (E) Statistical analysis of B-D ("P<0.01 vs. $0 \mu \mathrm{mol} / \mathrm{l})$. (F) The apoptotic rate was measured by flow cytometry following $48 \mathrm{~h}$ of treatment. MMF significantly increased apoptosis in HMCs ( $(\mathrm{P}<0.01$ vs. $0 \mu \mathrm{mol} / \mathrm{l})$. Values are expressed as the mean \pm standard deviation of six independent experiments. MMF, mycophenolic acid; HMC, human mesangial cell.

combination also interfered with the progression of mesangial cells in the $G_{0} / G_{1}$ and $S$ phase (Fig. $5 C$ ).

\section{Discussion}

Mesangial cells serve a number of functions in the renal glomerulus, including structural support of the capillary tuft, modulation of glomerular hemodynamics and phagocytic removal of macromolecules and immune complexes. These cells also have complex interactions with infiltrating inflammatory cells, responding and contributing to the amplification of inflammation, fibrosis and the development of glomerulosclerosis (14). The proliferation of mesangial cells is a common pathological feature of glomerular diseases, including $\operatorname{IgA}$ nephropathy and lupus nephritis (11). For these reasons, numerous studies have investigated the contribution of mesangial cells to the development of glomerulosclerosis (15). However, these studies have concentrated on cultured cells or animal models of glomerular injury and there have been few studies of human mesangial cells. Specific targeting of mesangial cell proliferation may more effectively retard the progress of glomerular disease.
In mouse renal tubular epithelial cells, CsA caused cell cycle arrest in the $\mathrm{G}_{0} / \mathrm{G}_{1}$ phase and inhibited DNA synthesis (16). These results are similar to those the present study obtained on human mesangial cells. Compared to Tac, CsA caused a marked increase in apoptosis in human mesangial cells. This response may be linked to the activation of pre-apoptotic pathways or to the release of cytochrome $\mathrm{c}$ into the cytosol (17-20).

The present study found that similarly to Tac and CsA, MP caused mesangial cell cycle arrest in the $G_{0} / G_{1}$ phase and prevented cells from entering the $\mathrm{S}$ phase. This is in agreement with a study by Bladh et al (21), who reported that glucocorticoids can decrease the percentage of cells in $S / G_{2} / M$ phase and impair the proliferation of human embryonic kidney 293 cells by suppressing nuclear factor $\kappa$-light-chain-enhancer of activated B-cell activity. Glucocorticoids exert an antiproliferative effect in numerous cell types (22-26); therefore, it was hypothesized that the anti-proliferative effect of MP may be due to induction of cyclin-dependent kinase inhibitors such as p21Cip1 or p57Kip2 (27,28). Alternatively, MP may suppress c-myc or cyclins, which are capable of stimulating cell cycle progression (19). In contrast to Tac, CsA and MP, MMF significantly 
A

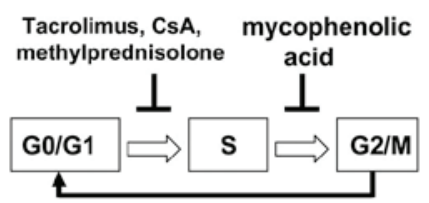

B

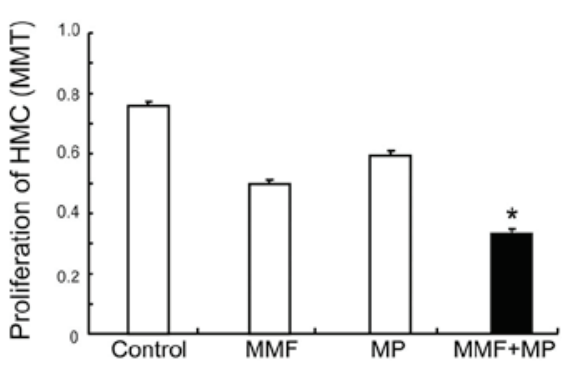

C

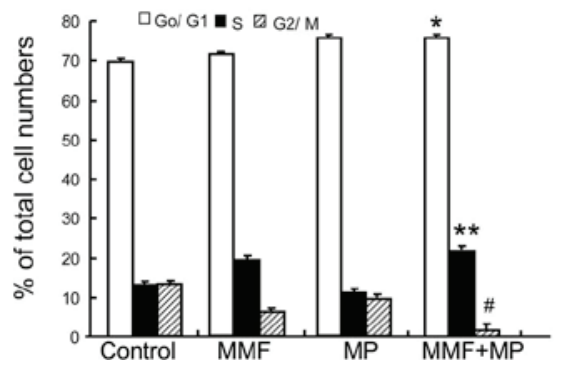

Figure 5. Different immunosuppressive agents target different phases of the cell cycle in HMCs. (A) Schematic displaying the actions of immunosuppressive agents on the cell cycle of HMCs. Calcineurin-inhibitors (Tac and CsA) and MP inhibit HMC proliferation by blocking cell entry into $S$ phase, while MMF blocks cell cycle progression by limiting $\mathrm{HMC}$ entry into $\mathrm{G}_{2} / \mathrm{M}$ phase. (B and $\mathrm{C}$ ) $\mathrm{MMF}$ $(2.5 \mathrm{mM})$ and MP $(1 \mathrm{mg} / \mathrm{l})$ synergistically inhibited the proliferation of HMCs by interfering with the cell cycle at $\mathrm{G}_{0} / \mathrm{G}_{1}$ phase and $\mathrm{S}$ phase $\left({ }^{*} \mathrm{P}<0.05\right.$ vs MMF; ${ }^{* *} \mathrm{P}<0.01$ vs. MP; ${ }^{*} \mathrm{P}<0.01$ vs. MMF or MP; values are presented as the mean \pm standard deviation $(\mathrm{n}=3)$. HMC, human mesangial cell; Tac, tacrolimus; CsA, cyclosporine A; MMF, mycophenolic acid; MP, methylprednisone.

inhibited mesangial cell growth by preventing cells from entering $\mathrm{G}_{2} / \mathrm{M}$ phase. This increased the percentage of cells in the $S$ phase and decreased the percentage of cells in $\mathrm{G}_{2} / \mathrm{M}$ phase.

The present study suggested a theoretical basis for sequential therapy with various immunosuppressive agents to treat glomerular diseases featuring mesangial proliferation. Sequential therapy with various immunosuppressive agents may limit the complications associated with steroid treatment or dependency and potentially provide an alternative treatment for steroid-resistant disease. It was found that the combination of MP and MMF was more effective at inhibiting mesangial cell proliferation.

In conclusion, Tac, CsA, MP and MMF suppressed human mesangial cell proliferation by targeting different phases of the cell cycle. A sequential therapy based on these differences may potentially be used as a strategy to treat proliferative glomerular diseases. Further studies to assess the in vivo responses of human mesangial cells to sequential therapy in mesangioproliferative disease models are required.

\section{Acknowledgements}

This study was supported by the Key Scientific and Technological Research Project Grant, Department of Public Health, Shanxi Province, China (grant no. 200919). The authors would like to thank Dr Xuewang Li for providing the human mesangial cells.

\section{References}

1. Akool el-S, Doller A, Babelova A, Tsalastra W, Moreth K, Schaefer L, Pfeilschifter J and Eberhardt W: Molecular mechanisms of TGF beta receptor-triggered signaling cascades rapidly induced by the calcineurin inhibitors cyclosporin $\mathrm{A}$ and FK506. J Immunol 181: 2831-2845, 2008.

2. Trachtman H, Vento s, Gipson D, et al: Novel therapies for resistant focal segmental glomerulosclerosis (FONT) phase II clinical trial: study design. BMC Nephrol 12: 8, 2011.

3. Ponticelli $\mathrm{C}$ and Passerini P: Other immunosuppressive agents for focal segmental glomerulosclerosis. Semin Nephrol 23: 242-248, 2003.

4. Sabuda-Widemann D, Grabensee B, Schwandt C and Blume C: Mycophenolic acid inhibits the autocrine PDGF-B synthesis and PDGF-BB-induced mRNA expression of Egr-1 in rat mesangial cells. Nephrol Dial Transplant 24: 52-61, 2009.

5. Radeke HH, Kuster S, Kaever V and Resch K: Effects of cyclosporin and FK-506 on glomerular mesangial cells. Evidence for direct inhibition of thromboxane synthase by low cyclosporin concentrations. Eur J Clin Pharmacol 44 (Suppl 1): S11-S16, 1993.

6. Miao L, Sun J, Yuan H, Jia Y and Xu Z: Combined therapy of low-dose tacrolimus and prednisone in nephrotic syndrome with slight mesangial proliferation. Nephrology (Carlton) 11: 449-454, 2006.

7. Pastukhov O, Schwalm S, Römer I, Zangemeister-Wittke U, Pfeilschifter J and Huwiler A: Ceramide kinase contributes to proliferation but not to prostaglandin E2 formation in renal mesangial cells and fibroblasts. Cell Physiol Biochem 34: 119-133, 2014.

8. Anil KMS, Irfan SM, Ranganna K, Malat G, Sustento-Reodica N, Kumar AM and Meyers WC: Comparison of four different immunosuppression protocols without long-term steroid therapy in kidney recipients monitored by surveillance biopsy: five-year outcomes. Transpl Immunol 20: 32-42, 2008.

9. Boletis J, Balitsari A, Filiopoulos V, Stamataki E, Lionaki S, Zavos G and Kostakis A: Delayed renal graft function: the influence of immunosuppression. Transplant Proc 37: 20542059,2005

10. Ren H, Guo N and Lu D: Successful engraftment of HLA-identical sibling cord blood transplantation in an adult with chronic myelogenous leukemia. Chinese Journal of Hematology 22: 621-624, 2001 (In Chinese).

11. Kurogi Y: Mesangial cell proliferation inhibitors for the treatment of proliferative glomerular disease. Med Res Rev 23: 15-31, 2003.

12. Delarue F, Virone A, Hagege J, Lacave R, Peraldi MN, Adida C, Rondeau E, Feunteun J and Sraer JD: Stable cell line of T-SV40 immortalized human glomerular visceral epithelial cells. Kidney Int 40: 906-912, 1991.

13. Ruan XZ, Varghese Z, Fernando R and Moorhead JF: Cytokine regulation of low-density lipoprotein receptor gene transcription in human mesangial cells. Nephrol Dial Transplant 13: 1391-1397, 1998.

14. Pereira RL, Felizardo RJ, Cenedeze MA, et al: Balance between the two kinin receptors in the progression of experimental focal and segmental glomerulosclerosis in mice. Dis Mod Mech 7: 701-710, 2014.

15. Liu CY, Zhou LL, Cheng Q, Jiang SN, Sheng J, Sun JD and Zhao JY: Effect of bradykinin on renal mesangial cell proliferation and extracellular matrix secretion. Genet Mol Res 13: 490-498, 2014.

16. Jennings P, Koppelstaetter C, Aydin S, Abberger T, Wolf AM, Mayer G and Pfaller W: Cyclosporine A induces senescence in renal tubular epithelial cells. Am J Physiol Renal Physiol 293: F831-F838, 2007.

17. Choi SJ, You HS and Chung SY: Tacrolimus-induced apoptotic signal transduction pathway. Transplant Proc 40: 2734-2736, 2008.

18. Migita K and Eguchi K: FK 506-mediated T-cell apoptosis induction. Transplant Proc 33: 2292-2293, 2001.

19. Park JW, Bae EH, Kim IJ, Ma SK, Choi C, Lee J and Kim SW: Paricalcitol attenuates cyclosporine-induced kidney injury in rats. Kidney Int 77: 1076-1085, 2010.

20. de Arriba G, de Hornedo JP, Rubio SR, Fernández MC, Martinez SB, Camarero MM and Cid TP: Vitamin E protects against the mitochondrial damage caused by cyclosporin $\mathrm{A}$ in LLC-PK1 cells. Toxicol Appl Pharmacol 239: 241-250, 2009. 
21. Bladh LG, Lidén J, Pazirandeh A, Rafter I, Dahlman-Wright K, Nilsson S and Okret S: Identification of target genes involved in the antiproliferative effect of glucocorticoids reveals a role for nuclear factor-(kappa)B repression. Mol Endocrinol 19: 632-643, 2005.

22. Rogatsky I, Trowbridge JM and Garabedian MJ: Glucocorticoid receptor-mediated cell cycle arrest is achieved through distinct cell-specific transcriptional regulatory mechanisms. Mol Cell Biol 17: 3181-3193, 1997.

23. Smith E, Redman RA, Logg CR, Coetzee GA, Kasahara N and Frenkel B: Glucocorticoids inhibit developmental stage-specific osteoblast cell cycle. Dissociation of cyclin A-cyclin-dependent kinase 2 from E2F4-p130 complexes. J Biol Chem 275: 19992-20001, 2000.

24. Rhee K, Reisman D, Bresnahan W and Thompson EA: Glucocorticoid regulation of G1 cyclin-dependent kinase genes in lymphoid cells. Cell Growth Differ 6: 691-698, 1995.
25. Helmberg A, Auphan N, Caelles C and Karin M: Glucocorticoid-induced apoptosis of human leukemic cells is caused by the repressive function of the glucocorticoid receptor. EMBO J 14: 452-460, 1995.

26. Sánchez I, Goya L, Vallerga AK and Firestone GL: Glucocorticoids reversibly arrest rat hepatoma cell growth by inducing an early G1 block in cell cycle progression. Cell Growth Differ 4: 215-225, 1993.

27. Corroyer S, Nabeyrat E and Clement A: Involvement of the cell cycle inhibitor CIP1/WAF1 in lung alveolar epithelial cell growth arrest induced by glucocorticoids. Endocrinology 138: 3677-3685, 1997.

28. Cha HH, Cram EJ, Wang EC, Huang AJ, Kasler HG and Firestone GL: Glucocorticoids stimulate p21 gene expression by targeting multiple transcriptional elements within a steroid responsive region of the $\mathrm{p} 21 \mathrm{waf} 1 / \mathrm{cip} 1$ promoter in rat hepatoma cells. J Biol Chem 273: 1998-2007, 1998. 